\title{
NO. 136
}

JUNE

2020

\section{KEY POINTS}

- Nonperforming loans (NPLs) are likely to rise in the period ahead. NPLs in emerging market economies reached $\$ 692$ billion in 2019 , up 2.5 times over 2009 and accounting for almost $40 \%$ of total global debt. In emerging Asia, NPLs more than tripled to $\$ 214$ billion (4.6\% of GDP) from $\$ 68$ billion during the same period. A sharp increase in NPLs could destabilize global banking systems and compromise swift economic recovery after the COVID-19 crisis passes.

- Empirical evidence shows that emerging market borrowers could suffer a significant increase in capital outflows if the NPL ratios of both lenders and borrowers rise. Globally active lenders withdrew capital from emerging market borrowers during 2000-2017 when they experienced a rise in NPL ratios.

- Early and even preemptive response is thus crucial to addressing NPL problems. The international community needs strong leadership to avoid a debt debacle, which could unfold soon if not properly addressed.
ISBN 978-92-9262-234-3 (print) ISBN 978-92-9262-235-0 (electronic) ISSN 2071-7202 (print) ISSN 2218-2675 (electronic) Publication Stock No. BRF200165-2 DOI: http://dx.doi.org/10.22617/BRF200165-2

\section{The Impact of Nonperforming Loans on Cross-Border Bank Lending: Implications for Emerging Market Economies ${ }^{1}$}

\author{
Cyn-Young Park \\ Asian Development Bank \\ Kwanho Shin \\ Professor \\ Department of Economics \\ Korea University
}

Director of Regional Cooperation and Integration

Economic Research and Regional Cooperation Department

\section{THE COVID-19 PANDEMIC COULD SPELL TROUBLE FOR GLOBAL BANKS}

The global economy is on the brink of a recession as the coronavirus disease (COVID-19) pandemic has severely impacted businesses, jobs, and incomes. The pandemic-induced economic slowdown is driven by both the supply and demand sides of the economy. As many economies have imposed lockdown measures, factories have been closed, supply chains disrupted, and productivity has fallen, with mounting economic losses. Job losses or reduced working hours due to quarantine or illness cut household incomes, lowering consumption. Firms' incentives to invest are also weakened as they face the elevated uncertainty.

Financial fragility in the banking system is thus one potential consequence of the pandemic. A pandemic-induced economic slowdown implies lower corporate earnings and higher unemployment, exacerbating the debt service burden for both firms and households. Many corporates and small and medium-sized enterprises, from airlines to retailers to restaurants, face risk of default. Growing job losses also imply a rise in household debts and mortgage defaults on the horizon. The banks that lend to them will likely suffer loan losses and rising nonperforming loans (NPLs).

The authors thank Yasuyuki Sawada for valuable comments and Mara Claire Tayag, Hyunjung Kim, and Jongwon Kim for excellent data support and research assistance. 
The economic impact of NPLs is well recognized in the financial literature. Bernanke (1983); Bernanke and Gertler (1989); and Bernanke, Gertler, and Gilchrist (1996) develop models of a financial accelerator to show how banks saddled with NPLs and weakened balance sheets restrict credits to the real sector, leading to low economic growth. Persistently high NPLs limit banks' profitability, tie up their capital due to high provisions, and deteriorate their balance sheet health, constraining capacity to lend.

Unresolved NPLs may also derail the post-COVID-19 economic recovery. Aiyar et al. (2015) illustrate that high NPL ratios are positively correlated with corporate debt overhangs, which depress corporate investment and delay economic recovery. Kalemli-Ozcan, Laeven, and Moreno (2018) show empirically that corporate debt overhang explained about $40 \%$ of the cumulative decline in aggregate investment of European firms over 4 years after the European debt crisis.

As the pandemic plagues developed and developing economies alike, concerns grow about a rise in NPLs and their transnational impacts on financial stability. This policy brief investigates the role of NPLs in cross-border bank lending by globally active banks in advanced economies. Emerging market economies can be vulnerable to a withdrawal of funds by major global lenders as NPLs rise in either emerging market economies or global lenders or both. Using Bank for International Settlements (BIS) statistics on banks' cross-border positions, evidence supports the role of NPLs in transmitting financial shocks through the global banking network when deteriorating macroeconomic conditions give rise to high NPLs among both lenders and borrowers.

\section{THE PANDEMIC COULD PUSH THE HEAVILY INDEBTED WORLD INTO A DEBT CRISIS}

The pandemic could trigger a recession in a world economy that is already heavily indebted. A decade of historically low interest rates since the global financial crisis of 2008-2009 has led to high debt to gross domestic product (GDP) ratios around the world (Figure 1). Total global debt is estimated to have reached $\$ 255$ trillion by the end of 2019 (over $320 \%$ of GDP) from $\$ 187$ trillion in 2009 (305\%) (Institute of International Finance 2020).

Debts have accumulated more sharply in emerging market economies than in the advanced economies over the past decade. In emerging Asia, total debt rose to $\$ 57$ trillion in 2019 (265\% of GDP) from $\$ 18$ trillion in 2009 (199\% of GDP), driven by particularly large increases in corporate and household sector debt. Aggressive fiscal policies fueled government debt issuance in many economies. Across all sectors (corporate, household, and government), debts will likely surge further as central banks around the world ease monetary policy and credit conditions for firms and households.

Mounting debt levels in both developed and developing economies can jeopardize global financial stability. NPLs will rise in the period ahead as the prospects for a severe economic downturn and high debt levels combine with temporary regulatory forbearance and accommodative monetary policy stances to mitigate the COVID-19 economic impact. Many studies attest to the positive relationship between economic downturn and high NPLs. Nkusu (2011) finds that adverse macroeconomic

Figure 1. Sectoral Indebtedness (\% of GDP)

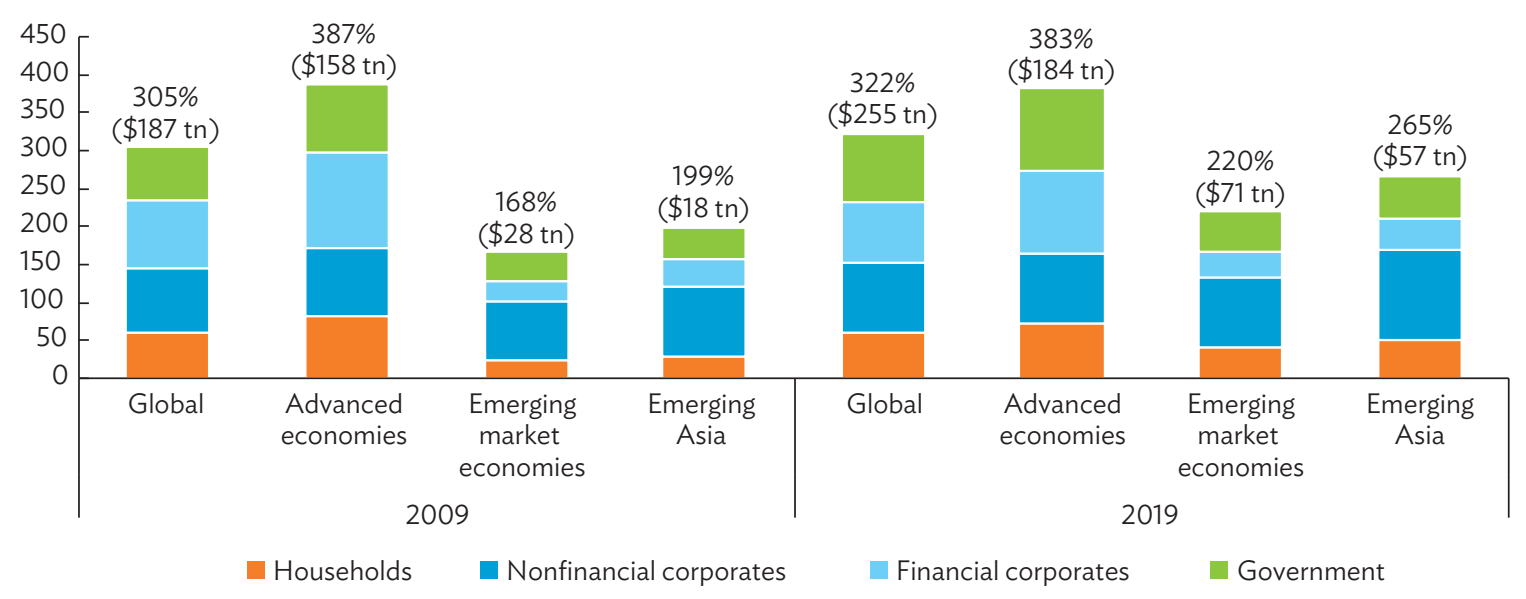

$\mathrm{GDP}=$ gross domestic product, $\mathrm{tn}=$ trillion .

Notes: The percentage and US dollar values refer to the total across all sectors per economy grouping. Economy grouping is based on the Institute of International Finance definition.

Source: Institute of International Finance. Global Debt Monitor Database. https://www.iif.com/ (accessed 4 May 2020). 
conditions-e.g., lower economic growth and higher unemployment levels - led to higher nonperforming loans in 26 developed economies during 1998 and 2009. Beck, Jakubik, and Piloiu (2015) investigate the macroeconomic determinants of NPLs across 91 economies to show that real GDP growth, stock prices, exchange rates, and bank lending rates significantly impact NPLs. Evidence also shows that NPLs are usually higher during recessionary periods with higher unemployment levels (Klein 2013; Nkusu 2011). Global risk factors also contribute to high NPLs. Espinoza and Prasad (2010) examine macroeconomic determinants for NPLs in about 80 banks in the Gulf Cooperation Council region. By employing the VIX index as a proxy for global risk aversion and tight financing conditions, they show that global financial volatility significantly increases nonperforming loans.

As Park and Shin (2020) show, banking interconnectedness implies that a shock hitting a particular bank or economy now transmits across national borders to affect multiple financial systems and economies. As made clear during the global financial crisis, financial stress in globally active banks could destabilize emerging market economies.

At that time, a sharp deterioration of United States (US) subprime mortgage loans triggered a wave of losses for banks and financial institutions, leading to a financial meltdown. Globally, shortterm lending dried up, and many troubled banks withdrew from emerging market economies to protect their capital. Cetorelli and Goldberg (2011) and Park and Shin (2020) find that cross-border bank lending played a significant role in the transmission of shocks in advanced economies to emerging market economies during the global financial crisis. Both argue that banks in advanced economies that were subject to a liquidity crunch reduced their cross-border lending, becoming a major international transmission channel for financial shock. Recent studies show that financial spillovers can be more substantial if the troubled banks in advanced economies are larger, more globally active, and systemically more important to global finance (de Haas and van Horen 2012; Hale, Kapan, and Minoiu 2016; Ivashina and Scharfstein 2010).

A sharp increase in NPLs could destabilize global banking systems and compromise swift economic recovery after the COVID-19 crisis. Ari, Chen, and Ratnovski (2019) examine NPL dynamics during 88 banking crises in 78 economies since 1990 and find a close relationship between high and persistent NPLs and large and persistent declines in output during post-crisis periods.

While bank-held NPLs declined in advanced economies from $\$ 1.7$ trillion at the end of 2009 to $\$ 935$ billion at the end of 2019 , NPLs in emerging market economies grew 2.5 times during the same period, reaching $\$ 692$ billion and accounting for almost $40 \%$ of the global total in 2019 (Figure 2a). The rise in NPLs in emerging Asia has been even more drastic as NPLs more than tripled to $\$ 214$ billion from $\$ 68$ billion during the same period. As a percentage of total gross loans, NPLs in emerging Asia also grew sharply, from $3.7 \%$ to $4.6 \%$; figures for emerging market economies remained relatively stable (Figure $2 b$ ).

\section{Figure 2. Nonperforming Loans of Deposit-Taking Financial Corporations}

(a) \$ billion

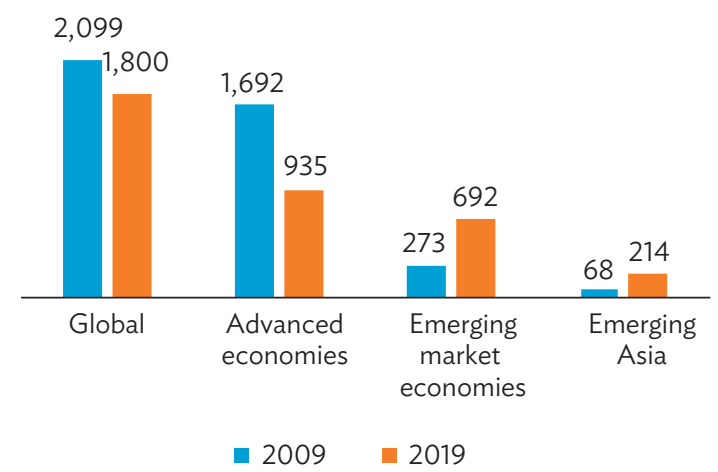

(b) $\%$ of total gross loans

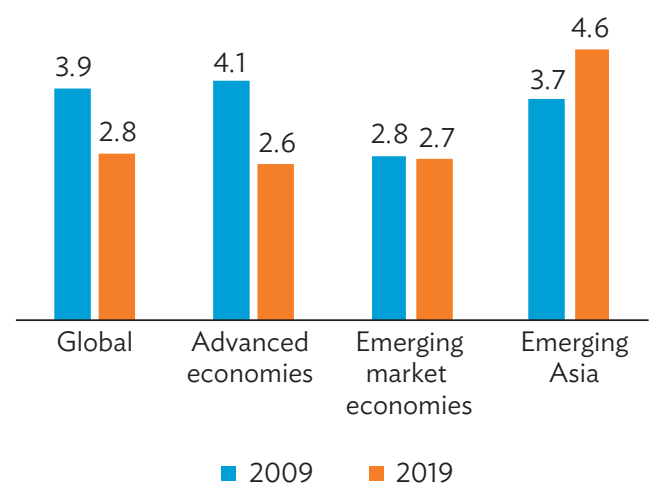

Notes:

(i) Where 2019 data are not available, 2018 data are used.

(ii) Advanced economies include Australia, Austria, Belgium, Cyprus, Czech Republic, Denmark, Estonia, France, Greece, Ireland, Italy, Japan, Latvia, Lithuania, Luxembourg, Malta, the Netherlands, Norway, Portugal, San Marino, Slovenia, Spain, Sweden, Switzerland, the United Kingdom, and the United States. Emerging Asia includes Armenia, Bangladesh, Georgia, India, Indonesia, Kazakhstan, the Kyrgyz Republic, Malaysia, Pakistan, the People's Republic of China, the Philippines, Singapore, Sri Lanka, Thailand, and Viet Nam. Emerging market economies include emerging Asia plus Albania, Argentina, Bosnia and Herzegovina, Brazil, Bulgaria, Chile, Colombia, Croatia, Dominican Republic, Ghana, Guatemala, Honduras, Hungary, Kenya, Lesotho, Mauritius, Mexico, Moldova, Nicaragua, Nigeria, Paraguay, Peru, Poland, Romania, Seychelles, South Africa, Tanzania, Turkey, Uganda, Ukraine, and Uruguay.

Source: International Monetary Fund. Financial Soundness Indicators. Downloaded via Haver Analytics (accessed 4 May 2020). 


\section{RISING NPLS COULD TRIGGER}

\section{GLOBAL BANKS' WITHDRAWAL}

\section{FROM EMERGING MARKET ECONOMIES}

The benchmark model specification ${ }^{2}$ estimates the impact of NPLs on banking outflows from emerging market economies:

$$
\text { Koutflow }_{i j t}=\alpha_{1} N P L r_{j t}+\alpha_{2} N P L r_{i t}+X_{i t} \beta+\gamma_{t}+\varepsilon_{i j t}
$$

where Koutflow ${ }_{i j t}$ is the growth rate of bilateral banking outflows from emerging market economy $i$ to lender economy $j$ at time $t$; $N P L r_{j t}$ is the NPL ratio of lender $j$ and NPL $r_{i t}$ is the NPL ratio of EME $i$ in year $t ; X_{i t}$ is a vector of economic fundamental variables ${ }^{3}$ of emerging market economy $i$ in year $t ; \gamma_{t}$ is aggregate time-fixed effects; and $\varepsilon_{i j t}$ is an idiosyncratic error term in year $t$.
The empirical model employed two separate datasets of BIS international banking statistics to compute bilateral banking flows: consolidated banking statistics (CBS) for total foreign claims on an immediate counterparty basis and the locational banking statistics (LBS) for total cross-border foreign claims. Annual data of 26 BIS reporting lenders and 67 emerging market economies as borrowers are analyzed for the sample period from 2000 to 2017. ${ }^{4}$ Emerging market economies are grouped into four different regions: Asia, Europe, North and South America, and Africa. ${ }^{5}$

Tables $1 \mathrm{a}$ and $1 \mathrm{~b}$ report the estimation results for the benchmark specification model. Columns (1)-(5) of Table 1a are estimated by pooled ordinary least squares (OLS). Year fixed effects are added in columns (3) and (5).

\section{Table 1a. Impact of Nonperforming Loans on Banking Outflows from Emerging Market Economies (CBS total foreign claims on an immediate counterparty basis)}

\begin{tabular}{|c|c|c|c|c|c|}
\hline Variables & (1) & (2) & (3) & (4) & (5) \\
\hline Nonperforming loan 1 & $\begin{array}{l}0.672^{* * *} \\
{[0.064]}\end{array}$ & $\begin{array}{c}0.708^{* * *} \\
{[0.082]}\end{array}$ & $\begin{array}{c}0.490^{* * *} \\
{[0.084]}\end{array}$ & $\begin{array}{c}0.655^{* * *} \\
{[0.085]}\end{array}$ & $\begin{array}{l}0.491^{* * *} \\
{[0.087]}\end{array}$ \\
\hline Nonperforming loan 2 & & $\begin{array}{c}0.424^{* * *} \\
{[0.052]}\end{array}$ & $\begin{array}{c}0.358^{* * *} \\
{[0.052]}\end{array}$ & $\begin{array}{c}0.446^{* * *} \\
{[0.060]}\end{array}$ & $\begin{array}{l}0.354^{* * *} \\
{[0.059]}\end{array}$ \\
\hline Increase in current account deficit & & & & $\begin{array}{c}0.149 \\
{[0.119]}\end{array}$ & $\begin{array}{l}-0.055 \\
{[0.122]}\end{array}$ \\
\hline Real exchange rate change & & & & $\begin{array}{l}0.427^{* * *} \\
{[0.091]}\end{array}$ & $\begin{array}{l}0.325^{* * *} \\
{[0.113]}\end{array}$ \\
\hline Increase in credit & & & & $\begin{array}{c}0.149^{* * *} \\
{[0.046]}\end{array}$ & $\begin{array}{c}0.050 \\
{[0.046]}\end{array}$ \\
\hline Reserve/M2 & & & & $\begin{array}{c}5.123^{*} \\
{[3.100]}\end{array}$ & $\begin{array}{c}5.219^{*} \\
{[3.087]}\end{array}$ \\
\hline GDP growth & & & & $\begin{array}{l}-0.244^{*} \\
{[0.144]}\end{array}$ & $\begin{array}{l}-0.373^{* *} \\
{[0.168]}\end{array}$ \\
\hline Inflation & & & & $\begin{array}{l}-0.018 \\
{[0.132]}\end{array}$ & $\begin{array}{r}0.030 \\
{[0.139]}\end{array}$ \\
\hline Rule of law & & & & $\begin{array}{c}2.261^{* * *} \\
{[0.837]}\end{array}$ & $\begin{array}{c}1.861^{* *} \\
{[0.837]}\end{array}$ \\
\hline $\begin{array}{l}\text { Year fixed effects } \\
\text { R-squared } \\
\text { Observations }\end{array}$ & $\begin{array}{c}\text { No } \\
0.008 \\
12,296\end{array}$ & $\begin{array}{c}\text { No } \\
0.022 \\
6,990\end{array}$ & $\begin{array}{l}\text { Yes } \\
0.069 \\
6,990\end{array}$ & $\begin{array}{c}\text { No } \\
0.040 \\
5,034\end{array}$ & $\begin{array}{l}\text { Yes } \\
0.084 \\
5,034\end{array}$ \\
\hline
\end{tabular}

GDP = gross domestic product.

Notes: The dependent variable is the growth rate of banking outflows calculated using consolidated banking statistics (CBS) total foreign claims on an immediate counterparty basis. Columns of (1)-(5) are estimated by pooled ordinary least squares. Year fixed effects are added in columns (3) and (5), but the coefficients are not reported. The sample period is from 2000 to 2017. Numbers in brackets are robust standard errors. The asterisks denote significance levels: ${ }^{* * *}$ at $1 \%$; ${ }^{* *}$ at $5 \%$; and ${ }^{*}$ at $10 \%$.

Source: Authors' calculations.

2 The benchmark model specification follows Shim and Shin (2018) except that this model employs the NPL ratio directly instead of financial stress measures

3 Economic fundamental variables include the increase in the ratio of current account deficits to GDP; real exchange rate appreciation; the increase in the total credit-to-GDP ratio over the past 3 years; and the current level of the ratio of reserves to M2, GDP growth, and inflation.

4 We have converted quarterly data into annual data. For example, the annual growth rate of bilateral banking outflows is calculated by taking the average of yearon-year growth rates of quarterly bilateral banking outflows in the same year.

5 Emerging market economies in Asia include Bangladesh; Hong Kong, China; India; Indonesia; Kazakhstan; the Kyrgyz Republic; Malaysia; Mongolia; Pakistan; the People's Republic of China; the Philippines; the Republic of Korea; Singapore; Sri Lanka; Thailand; and Taipei,China. 


\section{Table 1b. Impact of Nonperforming Loans on Banking Outflows from Emerging Market Economies (LBS total cross-border foreign claims)}

\begin{tabular}{|c|c|c|c|c|c|}
\hline Variables & (1) & (2) & (3) & (4) & (5) \\
\hline Nonperforming loan 1 & $\begin{array}{l}0.851^{* * *} \\
{[0.088]}\end{array}$ & $\begin{array}{l}0.909^{* * *} \\
{[0.114]}\end{array}$ & $\begin{array}{l}0.688^{* * *} \\
{[0.118]}\end{array}$ & $\begin{array}{l}0.875^{* * *} \\
{[0.119]}\end{array}$ & $\begin{array}{l}0.696^{* * *} \\
{[0.121]}\end{array}$ \\
\hline Nonperforming loan 2 & & $\begin{array}{l}0.519^{* * *} \\
{[0.044]}\end{array}$ & $\begin{array}{c}0.481^{* * *} \\
{[0.045]}\end{array}$ & $\begin{array}{l}0.587^{* * *} \\
{[0.051]}\end{array}$ & $\begin{array}{c}0.495^{* * *} \\
{[0.049]}\end{array}$ \\
\hline Increase in current account & & & & $\begin{array}{c}0.079 \\
{[0.136]}\end{array}$ & $\begin{array}{l}-0.114 \\
{[0.136]}\end{array}$ \\
\hline Real exchange rate change & & & & $\begin{array}{c}0.382^{* * *} \\
{[0.093]}\end{array}$ & $\begin{array}{l}-0.008 \\
{[0.115]}\end{array}$ \\
\hline Increase in credit & & & & $\begin{array}{c}0.045 \\
{[0.048]}\end{array}$ & $\begin{array}{l}-0.020 \\
{[0.048]}\end{array}$ \\
\hline Reserve/M2 & & & & $\begin{array}{c}3.909 \\
{[3.376]}\end{array}$ & $\begin{array}{c}4.967 \\
{[3.263]}\end{array}$ \\
\hline GDP growth & & & & $\begin{array}{l}-0.139 \\
{[0.153]}\end{array}$ & $\begin{array}{l}-0.631^{* * *} \\
{[0.176]}\end{array}$ \\
\hline Inflation & & & & $\begin{array}{l}-0.329^{* *} \\
{[0.133]}\end{array}$ & $\begin{array}{l}-0.103 \\
{[0.141]}\end{array}$ \\
\hline Rule of law & & & & $\begin{array}{c}0.705 \\
{[0.883]}\end{array}$ & $\begin{array}{c}0.770 \\
{[0.871]}\end{array}$ \\
\hline $\begin{array}{l}\text { Year fixed effects } \\
\text { R-squared } \\
\text { Observations }\end{array}$ & $\begin{array}{c}\text { No } \\
0.008 \\
11,113\end{array}$ & $\begin{array}{c}\text { No } \\
0.030 \\
6,176\end{array}$ & $\begin{array}{c}\text { Yes } \\
0.084 \\
6,176\end{array}$ & $\begin{array}{c}\text { No } \\
0.049 \\
4,428\end{array}$ & $\begin{array}{c}\text { Yes } \\
0.111 \\
4,428\end{array}$ \\
\hline
\end{tabular}

GDP = gross domestic product.

Notes: The dependent variable is the growth rate of banking outflows calculated using locational banking statistics (LBS) total cross-border foreign claims. Columns of (1)-(5) are estimated by pooled ordinary least squares. Year fixed effects are added in columns (3) and (5) but the coefficients are not reported. The sample period is from 2000 to 2017. Numbers in brackets are robust standard errors. The asterisks denote significance levels: ${ }^{* * *}$ at $1 \%$; ${ }^{* *}$ at $5 \%$; and ${ }^{*}$ at $10 \%$.

Source: Authors' calculations.

The results show that the coefficients of the NPL ratio of both lender (Nonperforming loan 1) and borrower (Nonperforming loan 2) economies are positive and highly statistically significant whether economic fundamental variables of emerging market economies are controlled or not and year fixed effects are included or not. The results indicate that international banks withdraw fund from emerging economies in response to the increase in the NPL ratios of either advanced or emerging economies or both. Table 1b, where the LBS is used to calculate banking outflows, presents essentially the same results. While the NPL ratios of both lenders and borrowers are positive and highly statistically significant in the pooled OLS regressions, the coefficient of the NPL ratio of the lenders is consistently greater than that of the NPL ratio of the borrowers. The results imply potentially significant and larger effects on banking outflows from emerging market economies if the NPL ratio rises in advanced economies.

Next, the model was extended to test whether internationally more active banks behave differently. Internationally more active banks are defined as those with total claims in all emerging market economies above the top 25th percentile. Recent studies have noted that the disruption in the US dollar funding market may affect the banks (and the economies) that are more active in cross-border lending and change their behavior relatively more in responding to a financial shock (Avdjiev, Eren, and McGuire 2020; Bruno and Shin 2015; IMF 2019; and Iñaki, Ehlers, and Eren 2018). Hence, the test will confirm whether and to what extent these globally active banks will respond to a rise in NPL ratios.

The estimation results using the sample of internationally more active investors are presented in Tables $2 \mathrm{a}$ (based on CBS) and $2 \mathrm{~b}$ (based on LBS). Table 2 a shows a much greater impact of the NPL rise among globally active lenders on capital outflows from emerging market economies. For example, a 1 percentage point increase in the NPL ratio in advanced and emerging market economies raises banking outflows from emerging market economies by 1.4 and 0.3 percentage points, respectively (Table $2 a$, Column 2 ). The sensitivity of banking outflows (by globally more active investors) to emerging market economies' NPL ratios is similar or less compared with the results in Table 1, but the sensitivity appears to be greater to their own NPL ratios although the coefficient loses its statistical significance when both the year fixed effects and economic fundamental variables of emerging market economies are included (column 5). But the coefficient of lenders' NPL ratio becomes mostly statistically insignificant in Table $2 b$. 
Table 2a. Impact of Nonperforming Loans on Banking Outflows from Emerging Market Economies: Internationally Active Lenders (CBS total foreign claims on an immediate counterparty basis)

\begin{tabular}{|c|c|c|c|c|c|}
\hline Variables & (1) & (2) & (3) & (4) & (5) \\
\hline Nonperforming loan 1 & $\begin{array}{l}1.307^{* * *} \\
{[0.228]}\end{array}$ & $\begin{array}{c}1.439^{* * *} \\
{[0.291]}\end{array}$ & $\begin{array}{c}0.815^{* *} \\
{[0.335]}\end{array}$ & $\begin{array}{c}1.489^{* * *} \\
{[0.336]}\end{array}$ & $\begin{array}{c}0.522 \\
{[0.380]}\end{array}$ \\
\hline Nonperforming loan 2 & & $\begin{array}{c}0.259^{* * *} \\
{[0.072]}\end{array}$ & $\begin{array}{l}0.219^{* * *} \\
{[0.073]}\end{array}$ & $\begin{array}{l}0.379^{* * *} \\
{[0.081]}\end{array}$ & $\begin{array}{c}0.279^{* * *} \\
{[0.079]}\end{array}$ \\
\hline Increase in current account & & & & $\begin{array}{c}0.137 \\
{[0.160]}\end{array}$ & $\begin{array}{l}-0.124 \\
{[0.163]}\end{array}$ \\
\hline Real exchange rate change & & & & $\begin{array}{l}0.700^{* * *} \\
{[0.121]}\end{array}$ & $\begin{array}{l}0.443^{* * *} \\
{[0.138]}\end{array}$ \\
\hline Increase in credit & & & & $\begin{array}{l}0.162^{* * *} \\
{[0.057]}\end{array}$ & $\begin{array}{c}0.061 \\
{[0.055]}\end{array}$ \\
\hline Reserve/M2 & & & & $\begin{array}{c}0.662 \\
{[4.097]}\end{array}$ & $\begin{array}{c}1.156 \\
{[4.037]}\end{array}$ \\
\hline GDP growth & & & & $\begin{array}{l}-0.106 \\
{[0.182]}\end{array}$ & $\begin{array}{l}-0.278 \\
{[0.206]}\end{array}$ \\
\hline Inflation & & & & $\begin{array}{l}-0.259 \\
{[0.176]}\end{array}$ & $\begin{array}{l}-0.113 \\
{[0.182]}\end{array}$ \\
\hline Rule of law & & & & $\begin{array}{c}1.329 \\
{[1.098]}\end{array}$ & $\begin{array}{c}1.166 \\
{[1.055]}\end{array}$ \\
\hline $\begin{array}{l}\text { Year fixed effects } \\
\text { R-squared } \\
\text { Observations }\end{array}$ & $\begin{array}{c}\text { No } \\
0.006 \\
5,662\end{array}$ & $\begin{array}{c}\text { No } \\
0.015 \\
3,004\end{array}$ & $\begin{array}{c}\text { Yes } \\
0.116 \\
3,004\end{array}$ & $\begin{array}{c}\text { No } \\
0.049 \\
2,202\end{array}$ & $\begin{array}{l}\text { Yes } \\
0.145 \\
2,202\end{array}$ \\
\hline
\end{tabular}

GDP = gross domestic product.

Notes: The dependent variable is the growth rate of banking outflows calculated using consolidated banking statistics (CBS) total foreign claims on an immediate counterparty basis. We define internationally more active economies by those whose total claims in all emerging market economies are above the top 25 th percentile. Columns (1)-(5) are estimated by pooled ordinary least squares. Year fixed effects are added in columns (3) and (5) but the coefficients are not reported. The sample period is from 2010 to 2017. Numbers in brackets are robust standard errors. The asterisks denote significance levels: ${ }^{* * *}$ at 1\%; ${ }^{* *}$ at 5\%; and * at $10 \%$.

Source: Authors' calculations.

Table 2b. Impact of Nonperforming Loans on Banking Outflows from Emerging Market Economies: Internationally Active Lenders (LBS total cross-border foreign claims)

\begin{tabular}{l|c|c|c|c|c} 
Variables & $(1)$ & $(2)$ & $(3)$ & $(4)$ & $(5)$ \\
\hline Nonperforming loan 1 & $0.705^{* *}$ & 0.476 & -0.052 & 0.455 & -0.214 \\
& {$[0.311]$} & {$[0.409]$} & {$[0.487]$} & {$[0.461]$} & {$[0.544]$} \\
\hline Nonperforming loan 2 & & $0.466^{* * *}$ & $0.414^{* * *}$ & $0.553^{* * *}$ & $0.437^{* * *}$ \\
& & {$[0.065]$} & {$[0.066]$} & {$[0.075]$} & {$[0.073]$} \\
\hline Increase in current account & & & & -0.046 \\
& & & & 0.212 & {$[0.198]$} \\
\hline Real exchange rate change & & & $0.417^{* * *}$ & 0.156 \\
\hline Increase in credit & & & $0.134]$ & {$[0.156]$} \\
\hline Reserve/M2 & & & 0.032 & -0.043 \\
& & & -0.474 & {$[0.065]$} \\
\hline
\end{tabular}


Table 2b. continued

\begin{tabular}{l|c|c|c|c|c}
\hline Variables & (1) & (2) & (3) & (4) & (5) \\
\hline GDP growth & & & & -0.315 & $-0.893^{* * *}$ \\
& & & & {$[0.233]$} & {$[0.285]$} \\
\hline Inflation & & & & $-0.420^{* *}$ & -0.250 \\
& & & & $0.213]$ & {$[0.224]$} \\
\hline Rule of law & & & 0.108 & -0.543 \\
& & & & {$[1.266]$} & {$[1.207]$} \\
\hline Year fixed effects & No & No & Yes & No & Yes \\
R-squared & 0.001 & 0.019 & 0.110 & 0.042 & 0.141 \\
Observations & 4,837 & 2,524 & 2,524 & 1,841 & 1,841 \\
\hline
\end{tabular}

GDP = gross domestic product.

Notes: The dependent variable is the growth rate of banking outflows calculated using locational banking statistics (LBS) total cross-border foreign claims. We define internationally more active economies by those whose total claims in all emerging market economies are above the top 25th percentile. Columns of (1)-(5) are estimated by pooled ordinary least squares. Year fixed effects are added in columns (3) and (5) but the coefficients are not reported. The sample period is from 2010 to 2017. Numbers in brackets are robust standard errors. The asterisks denote significance levels: ${ }^{* *}$ at $1 \%$; ${ }^{* *}$ at $5 \%$; and ${ }^{*}$ at $10 \%$.

Source: Authors' calculations.

Finally, do the same region lenders behave differently than nonregional lenders in response to the NPL ratio of both lender and borrower economies? Recent BIS data show that after the global financial crisis, Japan, the People's Republic of China, the Republic of Korea, and Singapore replaced European economies in lending to Asian economies. Park and Shin (2020) argued that the same region lenders showed more favorable behaviors toward emerging market economies during the global financial crisis. If their NPLs rose would they continue to behave favorably toward same-region borrowers? The benchmark model is modified by adding Region $n_{i j}$ as a dummy variable that takes 1 if emerging market economy $i$ and lender economy $j$ belong to the same region and 0 otherwise and its interactions with NPL ratios.

Presenting pooled OLS regression results, Table $3 a$ used CBS while Table 3b was based on LBS. Table 3a finds that the coefficient of the region dummy is negative and highly statistically significant, indicating that banking outflows from emerging market economies driven by the same-region lenders are on average $4 \%-7 \%$ lower. $^{6}$ However, the estimated coefficients of interaction terms imply that the sensitivity of banking outflows to the same-region lenders' NPL ratio is approximately twice as large as that of different regions' lenders. Table $3 \mathrm{~b}$ also shows that the same-region lenders' withdrawal from emerging market economies is on average 3\%-4\% lower. However, while the estimated coefficients of interaction terms are all positive, the statistical significance is lower than in Table 3a. Taken together, the findings suggest that on average the same-region lenders may withdraw less from emerging market economies than non-regional lenders. Nevertheless, the regional lenders react more sensitively to a rise in their own NPL ratios and could withdraw more capital from the same-region borrowers during financial turmoil.

\section{WHAT SHOULD POLICY MAKERS DO TO PREVENT THE PANDEMIC FROM TURNING INTO A DEBT CRISIS?}

Macroeconomic stimulus policies can help to alleviate future NPL problems as long as they can successfully facilitate the post-crisis economic recovery. A swift economic recovery will improve the quality of debts - especially additional debts in the context of fighting the COVID-19 pandemic - and therefore help avoid a rise in NPLs.

Across Asia and the Pacific, policy makers have implemented timely and bold policies to steer a speedy recovery. Luckily, most economies in Asia have strong underlying macroeconomic fundamentals and their banking systems are generally well capitalized with healthy balance sheets, providing a good backdrop for the post COVID-19 recovery. Large-scale stimulus packages by governments and central banks can help significantly decrease the probability of a recession. Until there is a clear sign of a recovery, it is important to maintain macro-financial policies that support economies and financial markets to underpin the post-crisis recovery.

Once the pandemic is contained, unwinding of COVID-19related debt has to be carefully managed. More than ever, the international community needs strong leadership to avoid a debt debacle, which could unfold as soon as an unwinding of policy stimulus starts if not properly addressed early. While coordinated policy efforts have been made to limit the immediate economic impact of the pandemic and support households, small businesses, and corporate borrowers, it is time to start preparing for systemic debt resolution and restructuring.

\footnotetext{
6 This negative coefficient of the region dummy also implies that, during the sample period, capital inflows from regional lenders are greater than from non-
} regional lenders. 
Table 3a. Regional Linkages and the Impact of Nonperforming Loans on Banking Outflows from Emerging Market Economies (CBS total foreign claims on an immediate counterparty basis)

\begin{tabular}{|c|c|c|c|c|c|}
\hline Variables & (1) & (2) & (3) & (4) & (5) \\
\hline Nonperforming loan 1 & $\begin{array}{l}0.523^{* * *} \\
{[0.089]}\end{array}$ & $\begin{array}{c}0.568^{* * *} \\
{[0.109]}\end{array}$ & $\begin{array}{l}0.317^{* * *} \\
{[0.110]}\end{array}$ & $\begin{array}{l}0.486^{* * *} \\
{[0.111]}\end{array}$ & $\begin{array}{c}0.292^{* *} \\
{[0.114]}\end{array}$ \\
\hline Nonperforming loan 2 & & $\begin{array}{c}0.329^{* * *} \\
{[0.065]}\end{array}$ & $\begin{array}{c}0.295^{* * *} \\
{[0.065]}\end{array}$ & $\begin{array}{l}0.412^{* * *} \\
{[0.071]}\end{array}$ & $\begin{array}{c}0.341^{* * *} \\
{[0.070]}\end{array}$ \\
\hline Nonperforming loan $1^{*}$ region & $\begin{array}{l}0.393^{* * *} \\
{[0.125]}\end{array}$ & $\begin{array}{c}0.326^{* *} \\
{[0.161]}\end{array}$ & $\begin{array}{l}0.442^{* * *} \\
{[0.159]}\end{array}$ & $\begin{array}{l}0.458^{* * *} \\
{[0.170]}\end{array}$ & $\begin{array}{c}0.544^{* * *} \\
{[0.169]}\end{array}$ \\
\hline Nonperforming loan $2^{*}$ region & & $\begin{array}{l}0.302^{* * *} \\
{[0.111]}\end{array}$ & $\begin{array}{c}0.197^{*} \\
{[0.110]}\end{array}$ & $\begin{array}{c}0.139 \\
{[0.121]}\end{array}$ & $\begin{array}{r}0.066 \\
{[0.119]}\end{array}$ \\
\hline Region & $\begin{array}{l}-3.985^{* * *} \\
{[0.834]}\end{array}$ & $\begin{array}{l}-5.650^{* * *} \\
{[1.277]}\end{array}$ & $\begin{array}{l}-5.443^{* * *} \\
{[1.233]}\end{array}$ & $\begin{array}{l}-6.761^{\text {***}} \\
{[1.415]}\end{array}$ & $\begin{array}{c}-6.339^{* * *} \\
{[1.371]}\end{array}$ \\
\hline Increase in current account deficit & & & & $\begin{array}{c}0.149 \\
{[0.119]}\end{array}$ & $\begin{array}{l}-0.055 \\
{[0.122]}\end{array}$ \\
\hline Real exchange rate change & & & & $\begin{array}{l}0.427^{* * *} \\
{[0.091]}\end{array}$ & $\begin{array}{l}0.325^{* * *} \\
{[0.113]}\end{array}$ \\
\hline Increase in credit & & & & $\begin{array}{l}0.149^{* * *} \\
{[0.046]}\end{array}$ & $\begin{array}{c}0.050 \\
{[0.046]}\end{array}$ \\
\hline Reserve/M2 & & & & $\begin{array}{c}5.123^{*} \\
{[3.100]}\end{array}$ & $\begin{array}{c}5.219^{*} \\
{[3.087]}\end{array}$ \\
\hline GDP growth & & & & $\begin{array}{l}-0.244^{*} \\
{[0.144]}\end{array}$ & $\begin{array}{l}-0.373^{* *} \\
{[0.168]}\end{array}$ \\
\hline Inflation & & & & $\begin{array}{l}-0.018 \\
{[0.132]}\end{array}$ & $\begin{array}{r}0.030 \\
{[0.139]}\end{array}$ \\
\hline Rule of law & & & & $\begin{array}{c}2.261^{* * *} \\
{[0.837]}\end{array}$ & $\begin{array}{c}1.861^{* *} \\
{[0.837]}\end{array}$ \\
\hline $\begin{array}{l}\text { Year fixed effects } \\
\text { R-squared } \\
\text { Observations }\end{array}$ & $\begin{array}{c}\text { No } \\
0.008 \\
12,296\end{array}$ & $\begin{array}{c}\text { No } \\
0.022 \\
6,990\end{array}$ & $\begin{array}{l}\text { Yes } \\
0.069 \\
6,990\end{array}$ & $\begin{array}{c}\text { No } \\
0.040 \\
5,034\end{array}$ & $\begin{array}{c}\text { Yes } \\
0.084 \\
5,034\end{array}$ \\
\hline
\end{tabular}

GDP = gross domestic product.

Notes: The dependent variable is the growth rate of banking outflows calculated using consolidated banking statistics (CBS) total foreign claims on an immediate counterparty basis. Region is a dummy variable that takes 1 if lender and borrower economies belong to the same region and 0 otherwise. All columns are estimated by pooled ordinary least squares regressions. Year fixed effects are added in columns (3) and (5) but the coefficients are not reported. The sample period is from 2000 to 2017 . Numbers in brackets are robust standard errors. The asterisks denote significance levels: ${ }^{* *}$ at $1 \%$; ${ }^{* *}$ at $5 \%$; and ${ }^{*}$ at $10 \%$.

Source: Authors' calculations.

\section{Table 3b. Regional Linkages and the Impact of Nonperforming Loans on Banking Outflows from Emerging Market Economies (LBS total cross-border foreign claims)}

\begin{tabular}{l|c|c|c|c|c} 
Variables & $(1)$ & $(2)$ & $(3)$ & $(4)$ & $(5)$ \\
\hline Nonperforming loan 1 & $0.489^{* * *}$ & $0.789^{* * *}$ & $0.490^{* *}$ & $0.824^{* * *}$ & $0.558^{* *}$ \\
& {$[0.150]$} & {$[0.186]$} & {$[0.196]$} & {$[0.211]$} & {$[0.221]$} \\
\hline Nonperforming loan 2 & & $0.426^{* * *}$ & $0.424^{* * *}$ & $0.525^{* * *}$ & $0.471^{* * *}$ \\
& & {$[0.049]$} & {$[0.049]$} & {$[0.055]$} & {$[0.053]$} \\
\hline Nonperforming loan 1*region & $0.695^{* * *}$ & 0.187 & 0.350 & 0.102 & 0.268 \\
& {$[0.185]$} & {$[0.235]$} & {$[0.239]$} & {$[0.251]$} & {$[0.255]$} \\
\hline \multicolumn{2}{r}{} & \multicolumn{2}{c}{ continued on next page }
\end{tabular}


Table 3b. continued

\begin{tabular}{|c|c|c|c|c|c|}
\hline Variables & (1) & (2) & (3) & (4) & (5) \\
\hline Nonperforming loan $2^{*}$ region & & $\begin{array}{c}0.276^{* * *} \\
{[0.103]}\end{array}$ & $\begin{array}{c}0.163 \\
{[0.102]}\end{array}$ & $\begin{array}{c}0.236^{* *} \\
{[0.112]}\end{array}$ & $\begin{array}{c}0.112 \\
{[0.111]}\end{array}$ \\
\hline Region & $\begin{array}{l}-3.704^{* * *} \\
{[0.834]}\end{array}$ & $\begin{array}{c}-3.050^{* *} \\
{[1.277]}\end{array}$ & $\begin{array}{c}-2.879^{* *} \\
{[1.233]}\end{array}$ & $\begin{array}{c}-4.155^{* * *} \\
{[1.415]}\end{array}$ & $\begin{array}{c}-4.081^{* * *} \\
{[1.371]}\end{array}$ \\
\hline Increase in current account deficit & & & & $\begin{array}{c}0.083 \\
{[0.136]}\end{array}$ & $\begin{array}{l}-0.105 \\
{[0.136]}\end{array}$ \\
\hline Real exchange rate change & & & & $\begin{array}{c}0.355^{* * *} \\
{[0.094]}\end{array}$ & $\begin{array}{l}-0.036 \\
{[0.116]}\end{array}$ \\
\hline Increase in credit & & & & $\begin{array}{c}0.053 \\
{[0.048]}\end{array}$ & $\begin{array}{l}-0.009 \\
{[0.048]}\end{array}$ \\
\hline Reserve/M2 & & & & $\begin{array}{c}4.544 \\
{[3.459]}\end{array}$ & $\begin{array}{r}5.699^{*} \\
{[3.356]}\end{array}$ \\
\hline GDP growth & & & & $\begin{array}{l}-0.109 \\
{[0.158]}\end{array}$ & $\begin{array}{l}-0.636^{* * *} \\
{[0.184]}\end{array}$ \\
\hline Inflation & & & & $\begin{array}{l}-0.342^{* *} \\
{[0.136]}\end{array}$ & $\begin{array}{l}-0.090 \\
{[0.143]}\end{array}$ \\
\hline Rule of law & & & & $\begin{array}{c}0.826 \\
{[0.899]}\end{array}$ & $\begin{array}{c}0.983 \\
{[0.886]}\end{array}$ \\
\hline $\begin{array}{l}\text { Year fixed effects } \\
\text { R-squared } \\
\text { Observations }\end{array}$ & $\begin{array}{c}\text { No } \\
0.008 \\
12,296\end{array}$ & $\begin{array}{c}\text { No } \\
0.022 \\
6,990\end{array}$ & $\begin{array}{c}\text { Yes } \\
0.069 \\
6,990\end{array}$ & $\begin{array}{c}\text { No } \\
0.040 \\
5,034\end{array}$ & $\begin{array}{l}\text { Yes } \\
0.084 \\
5,034\end{array}$ \\
\hline
\end{tabular}

GDP = gross domestic product.

Notes: The dependent variable is the growth rate of banking outflows calculated using locational banking statistics (LBS) total cross-border foreign claims. Region is a dummy variable that takes 1 if lender and borrower economies belong to the same region and 0 otherwise. All columns are estimated by pooled ordinary least squares regressions. Year fixed effects are added in columns (3) and (5) but the coefficients are not reported. The sample period is from 2000 to 2017 . Numbers in brackets are robust standard errors. The asterisks denote significance levels: ${ }^{* *}$ at $1 \%$; ** at $5 \%$; and ${ }^{*}$ at $10 \%$.

Source: Authors' calculations.

First, early action should be taken to preempt corporate defaults. Preventive debt restructuring gives companies a second chance at rehabilitating debts and provides banks more certainty in assessing the debt risks. Facilitating out-of-court enforcement of restructurings of distressed debt and foreclosures of financial collateral can help banks recover some value of unpaid debts or collateral without going to court, assisting early resolution.

Second, together with banks, national authorities should prepare clear action plans to resolve NPLs swiftly and effectively. These action plans should be facilitated by removing major obstacles to NPL resolution through accelerating insolvency reforms, addressing the legal and taxation issues, and developing distressed debt markets. It is also important to have accurate and reliable data on NPLs for mapping the extent of NPL problems and formulating timely policy responses.

Third, developing distressed asset markets allows banks and financial institutions to dispose of NPLs more easily. With a functioning secondary market for NPLs, banks can sell NPLs to interested third party buyers at fair and efficient market prices. Secondary markets for NPLs can be promoted by insolvency reforms, taxation, and other legal and institutional reforms to remove barriers to loan servicing and to the transfer of bank loans to third parties. With NPLs removed from their balance sheets, banks can expand their lending, limiting the impact of high NPLs on domestic credit and economic growth as well.

And finally, past crises have taught us lessons that stronger regional financial cooperation is crucial to avoiding a financial crisis and safeguarding financial stability. Asian policy makers should work together on improving financial resilience through crisis identification, mitigation, and responses. The region's policy makers should continue their efforts to strengthen regional macro-financial monitoring and surveillance, improve effective emergency liquidity support through regional financial safety net arrangements, and deepen local currency capital markets to reduce external funding for their long-term investment needs for sustainable development. 


\section{REFERENCES}

Aiyar, S., W. Bergthaler, J. Garrido, A. Ilyina, A. Jobst, K. Kang, D. Kovtun, Y. Liu, D. Monaghan, and M. Moretti. 2015. A Strategy for Resolving Europe's Problem Loans. IMF Staff Discussion Note. No. 15/19.

Ari, A., S. Chen, and L. Ratnovski. 2019. The Dynamics of NonPerforming Loans during Banking Crises: A New Database. IMF Working Paper. 19/272.

Avdjiev, S., E. Eren, and P. McGuire. 2020. Dollar Funding Costs during the COVID-19 Crisis through the Lens of the FX Swap Market. Bank for International Settlements Bulletin. No. 1.

Beck, R., P. Jakubik, and A. Piloiu. 2015. Key Determinants of NonPerforming Loans: New Evidence from a Global Sample. Open Economies Review. 26 (3): 525-550.

Bernanke, B. S. 1983. Nonmonetary Effects of the Financial Crisis in Propagation of the Great Depression. American Economic Review 73 (3): 257-276.

Bernanke, B. S. and M. Gertler. 1989. Agency Costs, Net Worth, and Business Fluctuations. American Economic Review. 79 (1): 14-31.

Bernanke, B. S., M. Gertler, and S. Gilchrist. 1996. The Financial Accelerator and the Flight to Quality. The Review of Economics and Statistics. 78 (1): 1-15.

Bruno, V. and H. S. Shin. 2015. Cross-Border Banking and Global Liquidity. Review of Economic Studies. 82 (2): 535-64.

Cetorelli, N. and L. Goldberg. 2011. Global Banks and International Shock Transmission: Evidence from the Crisis. IMF Economic Review. 59 (1): 41-76.

de Haas, R. and N. van Horen. 2012. International Shock Transmission after the Lehman Brothers Collapse: Evidence from Syndicated Lending. American Economic Review, Papers and Proceedings. 102 (3): 231-237.
Espinoza, R. A. and A. Prasad. 2010. Nonperforming Loans in the GCC Banking System and their Macroeconomic Effects. IMF Working Paper. 10/224.

Hale, G., T. Kapan, and C. Minoiu. 2016. Crisis Transmission in the Global Banking Network. IMF Working Paper. 16-91.

Iñaki, A., T. Ehlers, and E. Eren. 2018. Global Banks, Dollar Funding, and Regulation. BIS Working Papers. No. 708.

Institute of International Finance. 2020. Global Debt Monitor: COVID-19 Lights a Fuse. https://www.iif.com/Portals/O/Files/ content/Research/Global\%20Debt\%20Monitor_April2020.pdf.

International Monetary Fund (IMF). 2019. Chapter 5: Banks' Dollar Funding: A Source of Financial Vulnerability. Global Financial Stability Report: Lower for Longer. Washington, DC.

Ivashina, V. and D. S. Scharfstein. 2010. Bank Lending during the Financial Crisis of 2008. Journal of Financial Economics. 97 (3): 319-38.

Kalemli-Ozcan, S., L. Laeven, and D. Moreno. 2018. Debt Overhang, Rollover Risk, and Corporate Investment: Evidence from the European Crisis. NBER Working Paper Series. 24555.

Klein, N. 2013. Non-Performing Loans in CESEE: Determinants and Impact on Macroeconomic Performance. IMF Working Paper. No. 13/72.

Nkusu, M. 2011. Non-Performing Loans and Macrofinancial Vulnerabilities in Advanced Economies. IMF Working Paper. No. 11/161.

Park, C-Y and K. Shin. 2020. Contagion through National and Regional Exposures to Foreign Banks during the Global Financial Crisis. Journal of Financial Stability. 46, Article 100721, February.

Shim, I. and K. Shin. 2018. Financial Stress in Lender Countries and Capital Outflows from Emerging Market Economies. BIS Working Papers. No. 745.
About the Asian Development Bank

$A D B$ is committed to achieving a prosperous, inclusive, resilient, and sustainable Asia and the Pacific, while sustaining its efforts to eradicate extreme poverty. Established in 1966, it is owned by 68 members49 from the region. Its main instruments for helping its developing member countries are policy dialogue, loans, equity investments, guarantees, grants, and technical assistance.

ADB Briefs are based on papers or notes prepared by ADB staff and their resource persons. The series is designed to provide concise, nontechnical accounts of policy issues of topical interest, with a view to facilitating informed debate. The Department of Communications administers the series.

Notes:

ADB recognizes "Korea" as the Republic of Korea. In this publication, "\$” refers to United States dollars.
The views expressed in this publication are those of the authors and do not necessarily reflect the views and policies of ADB or its Board of Governors or the governments they represent. ADB encourages printing or copying information exclusively for personal and noncommercial use with proper acknowledgment of ADB. Users are restricted from reselling, redistributing, or creating derivative works for commercial purposes without the express, written consent of ADB.

Asian Development Bank

6 ADB Avenue, Mandaluyong City

1550 Metro Manila, Philippines

Tel +63286324444

Fax +63286362444

www.adb.org/publications/series/adb-briefs

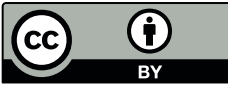

(C) 2020 ADB. The CC license does not apply to non-ADB copyright materials in this publication.

https://www.adb.org/terms-use\#openaccess http://www.adb.org/publications/corrigenda pubsmarketing@adb.org 